\title{
Trait-based metrics as bioindicators: Responses of stream fish assemblages to a gradient of environmental degradation
}

\author{
Fabrício Barreto Teresa ${ }^{\mathrm{a}, \mathrm{b}, *}$, Lilian Casatti ${ }^{\mathrm{b}}$ \\ a Universidade Estadual de Goiás, Câmpus de Ciências Exatas e Tecnológicas, 75.132-903, Anápolis, GO, Brazil \\ b UNESP-Universidade Estadual Paulista, Laboratório de Ictiologia, Departamento de Zoologia e Botânica, IBILCE, Rua Cristóvão Colombo, 2265, 15054-000, \\ São José do Rio Preto, SP, Brazil
}

\section{A R T I C L E I N F O}

\section{Article history:}

Received 4 February 2016

Received in revised form

30 September 2016

Accepted 21 December 2016

Available online 7 January 2017

\section{Keywords:}

Bioindicators

Context-dependent

Functional diversity

Trait-based metrics

\begin{abstract}
A B S T R A C T
The development of biomonitoring tools is increasingly appealing in light of the increasing degradation of aquatic ecosystems. In this context, we investigated the responses of stream fish communities to the gradient of environmental degradation in different basins using a variety of indices based on functional diversity, functional composition, and taxonomic diversity. We used datasets from three Brazilian ecoregions. In order to describe the gradient of environmental degradation we scored streams based on local and landscape variables. The functional structure of the assemblages was described in relation to seven functional traits related to habitat use, swimming capacity, and maneuverability. We described assemblages in each ecoregion separately in relation to 20 potential indicators, grouped in four families: indices of functional diversity based on presence/absence $\left(\mathrm{FD}_{\mathrm{p} / \mathrm{a}}\right)$; indices of functional diversity weighted by abundance $\left(\mathrm{FD}_{\mathrm{abund}}\right)$; indices of functional composition ( $\left.\mathrm{mT}\right)$; and, indices based on taxonomic diversity (TDiv). The relationship between the indicators and the gradient of environmental degradation were evaluated using linear regression. We found a significant interaction effect (ANOVA, $p=0.006$ ) between group of indices and ecoregions for the performance of indicators, suggesting a context-dependent response. The indices, on an individual basis, had variable performance and consistency among ecoregions. Four $\mathrm{mT}$ indicators demonstrated the highest average performance and consistency. Taxonomic diversity indicators consistently had the lowest average performance, while $\mathrm{FD}_{\mathrm{p} / \mathrm{a}}$ and $\mathrm{FD}_{\mathrm{abund}}$ indicators had low average performance and variable inter-regional consistency. The differential inter-regional performance of indicators was due to the differences in the lengths of the gradients of environmental degradation. Our results indicate that functional traits have greater predictive power compared to taxonomic indicators for fish responses to a gradient of environmental degradation. Although indicators of functional composition are the most promising, we emphasize that caution is needed when generalizing functional diversity indicators across ecoregions because most of them are context-dependent.
\end{abstract}

(c) 2016 Published by Elsevier Ltd.

\section{Introduction}

The search for biological correlates for environmental gradients is a fundamental step for using biological indicators in ecosystem quality assessments. However, bioindicators tend to present high variability in responses across different ecoregions, and therefore their use is usually context-dependent (Bonada et al., 2006). One of the main reasons for the non-transferability or limited usefulness of biological metrics across ecoregions is the difference in species

\footnotetext{
* Corresponding author at: Universidade Estadual de Goiás, Câmpus de Ciências Exatas e Tecnológicas, Anápolis 75.132-903, Brazil.

E-mail address: fabricioteresa@yahoo.com.br (F.B. Teresa).
}

composition; this is notably the case for metrics based on the taxonomic identity of species (Tolkamp, 1985). In view of this limitation, functional traits arose as good candidates and ecologically meaningful metrics for biomonitoring (functional trait indicators, sensu Moretti et al., 2009), and presumably are broadly applicable over biogeographic boundaries (Statzner et al., 2001). However, more extensive validation remains to be done, since the capacity of these indices in discriminating environmental gradients (i.e., performance) among taxa and ecosystems varies considerably (Moretti et al., 2009; Vandewalle et al., 2010).

The habitat templet (Southwood, 1977) and the habitat-filtering concepts (Tonn et al., 1990) provide a sound theoretical framework supporting the idea that communities described based on 
species traits should reveal convergent patterns. These theories have been extended for lotic ecosystems (Poff, 1997; Townsend and Hildrew, 1994) and show strong predictive power (Ibañez et al., 2009), with enormous potential for applied purposes. Indeed, there is an increasing trend of including trait-based approaches in monitoring and river assessments (Dolédec et al., 1999; Pont et al., 2006). More importantly, the trait-based approach provides a more mechanistic perspective of the species-environment relationship, since the response of a species to environmental gradients is determined by the set of traits influencing its performance and persistence (Violle et al., 2007).

Functional trait indicators can be summarized in two groups. One is based on the mean trait values ( $\mathrm{mT}$ - mean of traits, sensu Moretti et al., 2009), representing the dominant functional attribute in a community (Lavorel et al., 2008). The other is based on the range of traits in the community (i.e., FD - functional diversity, sensu Moretti et al., 2009), that, in turn, may be expressed by different metrics (e.g., Laliberté and Legendre, 2010; Petchey and Gaston, 2002; Villéger et al., 2008). Some indices include species abundance in their calculation and others do not. This feature may have consequences for how well the metrics will predict environmental gradients (de Bello et al., 2007; Mouillot et al., 2013a). For example, FD indices based on presence/absence $\left(\mathrm{FD}_{\mathrm{p} / \mathrm{a}}\right)$ are influenced by loss or gain of functional traits in the community, which means that their change depends on extirpation or addition of species with particular traits in the community. By contrast, FD metrics based on species abundance $\left(\mathrm{FD}_{\text {abund }}\right)$ may detect changes in assemblages associated with changes in species abundance, before the loss of species occurs, making them potentially more sensitive to environmental changes (Mouillot et al., 2013a). Therefore, we may expect that $\mathrm{FD}_{\mathrm{p} / \mathrm{a}}$ and $\mathrm{FD}_{\mathrm{abund}}$ would perform differently depending on how broad the environmental gradient is, with $\mathrm{FD}_{\mathrm{p} / \mathrm{a}}$ better predicting changes in assemblages along a broader environmental gradient, due to the high turnover of species and traits. Conversely, $\mathrm{FD}_{\text {abund }}$ would be a better indicator for narrower gradients, where changes in relative abundance among species are expected be more important than species turnover. Finally, changes in abundance and species turnover while maintaining overall diversity could influence $\mathrm{mT}$ because dominant traits would respond to filters operating across the gradient (Keck et al., 2014).

Stream fish assemblages respond markedly to human impacts in the aquatic environment (e.g., habitat degradation), but also to the alteration in landscape context (e.g., land use conversion) (Allan, 2004). The response of stream fish to land use and habitat degradation has been widely assessed from a taxonomic perspective (Allan, 2004; Casatti et al., 2006; Esselman and Allan, 2010), but more recently, the influences on the functional structure of assemblages have also been studied. The functional composition and functional diversity of stream fish communities have been shown to vary predictably along environmental gradients and human impacts (Pool et al., 2010; Casatti et al., 2012; Keck et al., 2014). Loss of benthic and rheophilic species, poorly adapted for physical habitat degradation, while allowing colonization by pool-dwelling species are examples of trait-mediate changes in assemblage structure along gradients of physical habitat degradation (Casatti et al., 2012). Therefore, fish represent a potential target group for ecosystem quality assessment through a multifaceted approach.

In this context, the aim of our study was to investigate the capability of different diversity indicators to summarize the responses of fish communities across environmental gradients in streams. More specifically, we evaluated which indicators (taxonomic diversity, $\mathrm{mT}, \mathrm{FD}_{\mathrm{p} / \mathrm{a}}$, and $\mathrm{FD}_{\mathrm{abund}}$ ) performed best at discriminating stream assemblages across gradients of land use and habitat degradation. We studied the response of fish assemblages in three distinct Neotropical ecoregions, Tocantins-Araguaia (TA); Upper Paraná (UPA), and Madeira Brazilian Shield (MA), which have different intensities and histories of land use. These differences allowed us to test to what extent the response of stream fish assemblages to anthropogenic environmental gradients can be generalized. Near pristine streams predominate in TA, as the landscape is still little impacted by anthropogenic activities (Borges et al., 2015), contrasting with UPA in the southeast of Brazil, where streams drain landscapes with higher levels of anthropogenic impacts, as this region lacks large forest remnants (Casatti et al., 2015a). The gradient of environmental degradation is broader in MA, with stream drainages varying from highly degraded to entirely forested (Bordignon et al., 2015).

We expect that functional indicators of diversity would outperform taxonomic indicators in predicting the gradient of environmental degradation, but that metrics would differ in their performance according to the differences in the gradient length. Indicators of functional diversity $\left(\mathrm{FD}_{\mathrm{p} / \mathrm{a}}\right.$ and $\left.\mathrm{FD}_{\text {abund }}\right)$ and functional composition ( $\mathrm{mT}$ ) should be able to better explain variation in the structure of assemblages in ecoregions with broader gradients (i.e., the Madeira ecoregion), because environmental changes should be enough to alter relative abundance and species composition. Furthermore, the predictive power of functional diversity metrics weighted by abundance $\left(\mathrm{FD}_{\mathrm{abund}}\right)$ and functional composition ( $\mathrm{mT}$ ) should be greater in regions with narrower gradients (i.e., the Tocantins-Araguaia and Upper Paraná ecoregions) because, in these conditions, changes in species abundance are more important than changes in species composition. Therefore, we predict that the correlation between fish indicators with the gradient of environmental degradation will vary among group of indicators and among ecoregions, with different indicators performing better in specific contexts.

\section{Material and methods}

\subsection{General sampling design and study area}

In order to assess the performance of each indicator at predicting the gradient of environmental degradation, we correlated ten FD, seven $\mathrm{mT}$, and three taxonomic indices for stream fish communities at the reach scale with an environmental gradient summarizing the land use and habitat conditions. We used three sets of data gathered from three different ecoregions of Brazil (sensu Abell et al., 2008): the Machado River basin, Madeira Brazilian Shield ecoregion (MA); the Santa Teresa basin, Tocantins-Araguaia ecoregion (TA); and the São José dos Dourados/Turvo-Grande basin, Upper Paraná ecoregion (UPA) (Fig. 1). The spatial extents within each region were about $460 \mathrm{~km}$ in MA, $100 \mathrm{~km}$ in TA, and $300 \mathrm{~km}$ in UPA (Fig. 1).

The Machado River basin drains the most populated area of the State of Rondônia, in Northern Brazil, with a total catchment area of $75,400 \mathrm{~km}^{2}$. This region has been altered by anthropogenic activities since 1970, with settlements along the highway BR-364 (Alves et al., 1998). The watersheds that form the Machado River basin are covered by forests (mature and secondary, ranging from 0 to $100 \%$ coverage) or grasslands which are used as pasture for cattle ranching (Fernandes and Guimarães, 2002).

The Santa Teresa River basin belongs to the Upper Tocantins River system, a macro-regional division of the Tocantins-Araguaia ecoregion. This basin is in the Cerrado biome (Brazilian savanna). Human occupation started around 1930 and has been intensifying since 1970, with the building of the Belém-Brasília highway, which has stimulated the conversion of native coverage to pasture for livestock grazing (Ministério do Meio Ambiente, 2006). Despite land conversion, the Santa Teresa basin still harbors approximately $70 \%$ of the native vegetation, mainly in the highest portions of the basin (Borges et al., 2015). 

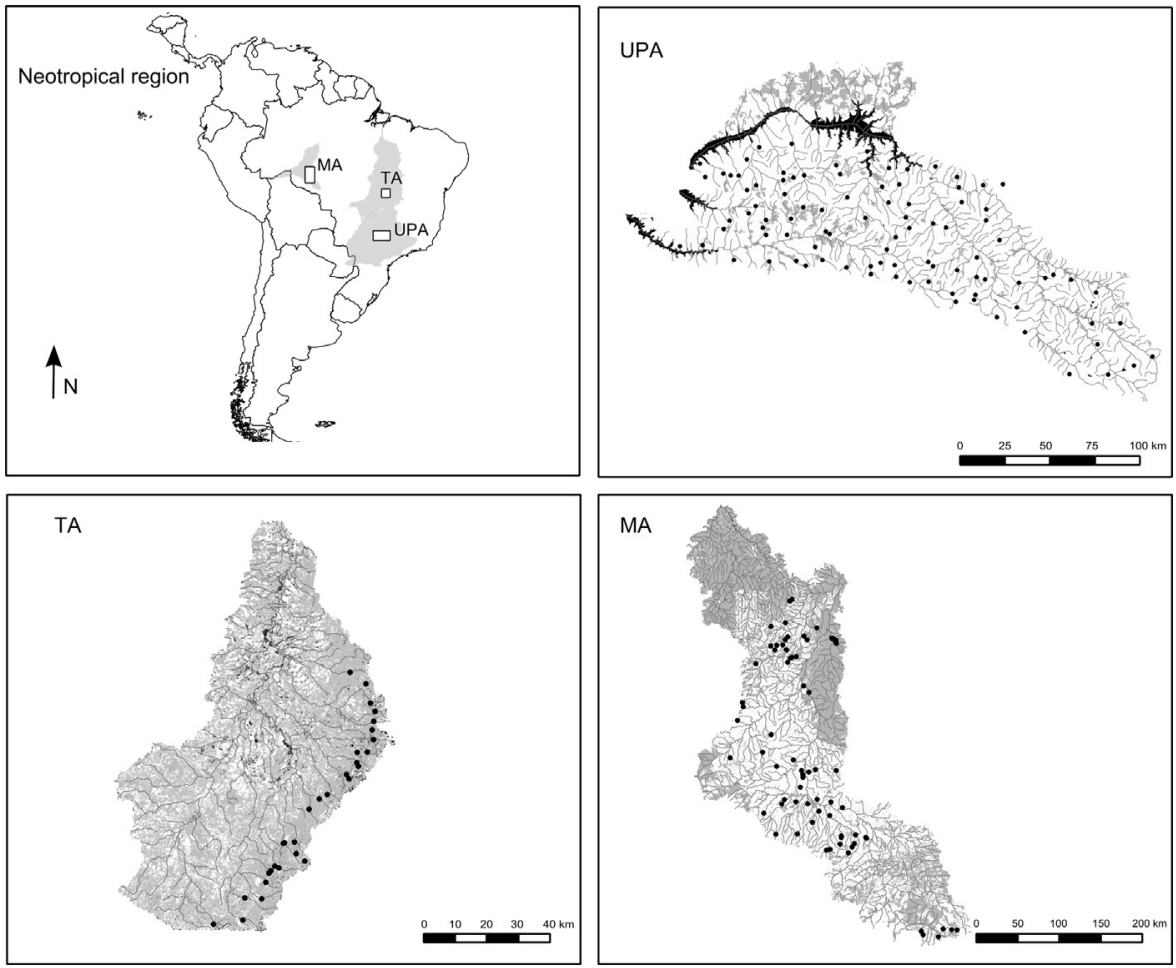

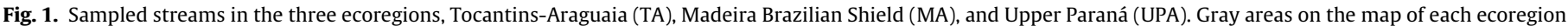
are native vegetation remnants.

The São José dos Dourados and Turvo-Grande rivers drain the northwest region of the State of São Paulo, located in southeastern Brazil. This region was originally covered by Semi-Deciduous Seasonal forests (Silva et al., 2007). Since the second half of the 20th century, this region has experienced high rates of deforestation; initially for the development of coffee crops, that were replaced by pasture for livestock grazing from 1929 onwards (Monbeig, 1998). More recently, pasture has been replaced by sugarcane crops and only $4 \%$ of the original vegetation coverage remains (Nalon et al., 2008), in small and isolated fragments (Silva et al., 2007).

The three datasets include samples taken from 72 streams in MA, 29 in TA, and 91 in UPA (Fig. 1). Sampling was conducted in streams with the greatest differences in forest cover as possible. This gradient was more evident in streams in MA, which exhibited a broader range of environmental conditions compared to the narrower conditions in the other two ecoregions; the landscape in TA is still little impacted by anthropogenic activities (Borges et al., 2015), while the landscape in UPA is severely modified by human activities (Casatti et al., 2015a). Streams were not under urban influence and there is no evidence of anthropogenic activities associated with water pollution.

\subsection{Fish sampling and environmental variables}

Sample reaches varied from 1st to 3rd order (Sthraler, 1957) and fish were collected using electrofishing (in TA and UPA) and seine and dip nets (in MA) (see detailed methods in Bordignon et al., 2015; Casatti et al., 2015a,b). All stream reaches were sampled once in the dry season and their length was similar across regions (75-m in UPA; 80-m in TA and MA).

The environmental variables dataset included indicators of land use, habitat degradation and hydrological variables. Despite a few differences in the field protocols among regions, the overall characterization of stream reaches was comparable and included the instream habitat, the riparian ecotone, and the catchment land cover. All stream reaches were characterized in relation to native vegetation cover in the catchment, proportion of trees and shrubs in the riparian zone, proportion of sand in the stream bottom, depth, width, and water current velocity.

We recorded the most appropriate variables for the measurement of the environmental degradation in the context of each ecoregion, thus not all variables were recorded in every ecoregion. In MA, we estimated the proportion of coarse litter in the stream bottom, since litter and fallen leaves have been shown to provide a reliable environmental indicator of habitat quality in Amazonian streams (Bordignon et al., 2015; Kemenes and Forsbergb, 2014). We also calculated the proportion of macrophytes in UPA because macrophytes (mostly derived from the surrounding pasture) represent a common cover in highly deforested lowland streams (Teresa and Casatti, 2012). The proportion of native vegetation cover in a 500-m buffer around each site's catchment was used as a complementary indicator of the integrity of the surrounding vegetation in $\mathrm{TA}$, given the apparent low variability of native vegetation cover in the whole catchment. These variables are good surrogates for the watershed's conservation status and local physical habitat integrity (Casatti et al., 2006; Poole and Downing, 2004).

Variables describing instream habitat conditions and riparian ecotones were measured in transversal equidistant transects along each sampled reach. The proportion of consolidated substrate, coarse litter, and aquatic macrophytes were visually estimated. Depth and wet width were measured using a meter ruler and measuring tape, respectively. Water current velocity was measured with a mechanical flow meter. Land use variables were obtained by using RapidEye imagery with a resolution of $5 \mathrm{~m}$ (TA) and Landsat 5 TM with a resolution of $30 \mathrm{~m}$ (MA and UPA), made available by the Ministério do Meio Ambiente and Instituto Nacional de Pesquisas Espaciais (INPE), respectively. The catchment limits and the drainage network were generated using satellite images 
Table 1

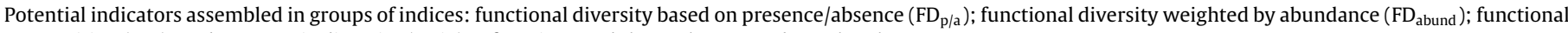
composition (mT); and taxonomic diversity (TDiv). R functions and the packages used are also shown.

\begin{tabular}{|c|c|c|c|}
\hline Group & Potential indicators & Description & Function (package) \\
\hline \multirow[t]{5}{*}{$\begin{array}{l}\text { Functional Diversity } \\
\left(\mathrm{FD}_{\mathrm{p} / \mathrm{a}}\right)\end{array}$} & $\mathrm{MPD}^{\mathrm{a}}$ & $\begin{array}{l}\text { Mean pairwise functional distance of species in the } \\
\text { community, using the raw Euclidian distance among species. }\end{array}$ & mpd (picante) \\
\hline & MNTD $^{\mathrm{a}}$ & $\begin{array}{l}\text { Mean functionally nearest species distance, using the raw } \\
\text { Euclidian distance among species. }\end{array}$ & mntd (picante) \\
\hline & $\mathrm{FD}^{\mathrm{b}}$ & $\begin{array}{l}\text { Total branch length of a functional dendrogram (Petchey and } \\
\text { Gaston, 2002). }\end{array}$ & pd (picante) \\
\hline & FRic $^{\mathrm{C}}$ & $\begin{array}{l}\text { Volume of the convex hull generated by species position in the } \\
\text { multidimensional functional trait space (Villéger et al., 2008). }\end{array}$ & $\mathrm{dbFD}(\mathrm{FD})$ \\
\hline & FGR $^{\mathrm{d}}$ & Richness of functional groups. & $\mathrm{dbFD}(\mathrm{FD})$ \\
\hline \multirow{5}{*}{$\begin{array}{l}\text { Functional Diversity } \\
\left(\text { FD }_{\text {abund }}\right)\end{array}$} & $\operatorname{MPD}_{\mathrm{a}}{ }^{\mathrm{a}}$ & MPD weighted by species abundance. & mpd (picante) \\
\hline & $\operatorname{MNTD}_{\mathrm{a}}^{\mathrm{a}}$ & MNTD weighted by species abundance. & mntd (picante) \\
\hline & FDiv $^{\mathrm{c}}$ & $\begin{array}{l}\text { Measures how abundance is distributed within the volume of } \\
\text { functional trait space occupied by species, being high when } \\
\text { more abundant species have extreme trait values (Villéger } \\
\text { et al., 2008). }\end{array}$ & $\mathrm{dbFD}(\mathrm{FD})$ \\
\hline & FDis $^{\mathrm{e}}$ & $\begin{array}{l}\text { Mean distance of individual species in a multidimensional trait } \\
\text { space to the centroid of all species, which in turn is dislocated } \\
\text { towards the most abundant species (Villéger et al., 2008). }\end{array}$ & $\mathrm{dbFD}(\mathrm{FD})$ \\
\hline & $\operatorname{Rao}^{f}$ & $\begin{array}{l}\text { The sum of the functional dissimilarity among all possible } \\
\text { pairs of species, weighted by the product of the species' } \\
\text { relative abundances (Pavoine and Dolédec 2005). }\end{array}$ & $\mathrm{dbFD}(\mathrm{FD})$ \\
\hline \multirow[t]{7}{*}{$\begin{array}{l}\text { Functional } \\
\text { Composition }\left(\mathrm{mT}^{g}\right)\end{array}$} & $\mathrm{mT}(\mathrm{RD})$ & $\begin{array}{l}\mathrm{mT}(\mathrm{RD})=\sum_{1}^{S} p_{i} \mathrm{RD}_{i} \text {, where } \mathrm{S} \text { is the number of species in the } \\
\text { community, and } \mathrm{RD}_{i} \text { the value of relative depth of the i-th } \\
\text { species in a sample. }\end{array}$ & functcomp (FD) \\
\hline & $\mathrm{mT}(\mathrm{RCP})$ & $\begin{array}{l}\mathrm{mT}(\mathrm{RCP})=\Sigma_{1}^{S} p_{i} \mathrm{RCP}_{i} \text {, where } \mathrm{S} \text { is the number of species in the } \\
\text { community and } \mathrm{RCP}_{i} \text { the value of relative caudal peduncle } \\
\text { length of the i-th species in a sample. }\end{array}$ & functcomp (FD) \\
\hline & $\mathrm{mT}(\mathrm{CPC})$ & $\begin{array}{l}\mathrm{mT}(\mathrm{CPC})=\Sigma_{1}^{S} p_{i} C P C_{i} \text {, where } \mathrm{S} \text { is the number of species in the } \\
\text { community, and } \mathrm{CPC}_{i} \text { the value of caudal peduncle } \\
\text { compression index of the i-th species in a sample. }\end{array}$ & functcomp (FD) \\
\hline & $\mathrm{mT}(\mathrm{IVF})$ & $\begin{array}{l}\mathrm{mT}(\mathrm{IVF})=\Sigma_{1}^{S} p_{i} \mathrm{IVF}_{i} \text {, where } \mathrm{S} \text { is the number of species in the } \\
\text { community, and } \mathrm{IVF}_{i} \text { the value of index of ventral flattening of } \\
\text { the i-th species in a sample. }\end{array}$ & functcomp (FD) \\
\hline & $\mathrm{mT}(\mathrm{RAP})$ & $\begin{array}{l}\mathrm{mT}(\mathrm{RAP})=\Sigma_{1}^{S} p_{i} \mathrm{RAP}_{i} \text {, where } \mathrm{S} \text { is the number of species in the } \\
\text { community, and } \mathrm{RAP}_{i} \text { the value of relative area of pectoral fin } \\
\text { of the i-th species in a sample. }\end{array}$ & functcomp (FD) \\
\hline & $\mathrm{mT}(\mathrm{EP})$ & $\begin{array}{l}\mathrm{mT}(\mathrm{EP})=\Sigma_{1}^{S} p_{i} \mathrm{EP}_{i} \text {, where } \mathrm{S} \text { is the number of species in the } \\
\text { community, and } \mathrm{EP}_{i} \text { the value of relative eye position of the } \\
\text { i-th species in a sample. }\end{array}$ & functcomp (FD) \\
\hline & $\mathrm{mT}(\mathrm{FC})$ & $\begin{array}{l}\mathrm{mT}(\mathrm{FC})=\Sigma_{1}^{S} p_{i} \mathrm{FC}_{i} \text {, where } \mathrm{S} \text { is the number of species in the } \\
\text { community, and } \mathrm{FC}_{i} \text { the value of fineness coefficient of the i-th } \\
\text { species in a sample. }\end{array}$ & functcomp (FD) \\
\hline \multirow{3}{*}{$\begin{array}{l}\text { Taxonomic diversity } \\
\text { (TDiv) }\end{array}$} & Richness & Number of species per site. & specnumber (vegan) \\
\hline & Simpson ${ }^{\mathrm{h}}$ & $\begin{array}{l}\text { Equal to one minus Simpson's original measure of dominance } \\
\text { (D). } D=\sum_{i=1}^{S} p_{i}^{2} \text {, where } \mathrm{S} \text { is the number of species in the } \\
\text { community, and pi the proportion of the i-th species in a } \\
\text { sample. }\end{array}$ & diversity (vegan) \\
\hline & Shannon $^{\mathrm{i}}$ & $\begin{array}{l}\text { Index of Shannon }\left(\mathrm{H}^{\prime}\right): \mathrm{H}^{\prime}=\mathrm{H}^{\prime}=\Sigma_{i=1}^{S} p_{i} x \ln _{p i} \text {, where } \mathrm{S} \text { is the } \\
\text { number of species in the community, and pi the proportion of } \\
\text { the i-th species in a sample. }\end{array}$ & diversity (vegan) \\
\hline
\end{tabular}

\footnotetext{
a Webb (2000).

b Petchey and Gaston, (2002).

c Villéger et al. (2008).

d Walker, (1992).

e Laliberté and Legendre, (2010).

f Pavoine and Dolédec, (2005).

g Garnier et al. (2004).

h Simpson (1949).

i Shannon (1948).
}

from the Digital Elevation Model (DEM) SRTM (90 m resolution) and made freely available by the United States Geological Survey (USGS).

\subsection{Functional traits}

Species from the three ecoregions were characterized in relation to the same seven functional traits, thus making possible the comparison of functional diversity and composition patterns between ecoregions. All functional traits were based on morphological features which relate to habitat use, swimming capacity, and maneuverability (Oliveira et al., 2010; Watson and Balon, 1984). Relative depth (RD), relative caudal peduncle length (RCP), caudal peduncle compression index (CPC), index of ventral flattening (IVF), relative area of pectoral fin (RAP), relative eye position (EP), and fineness coefficient (FC) were all adopted as functional traits. Habitat use and locomotion are important niche dimensions, which are associated with the response of fish to habitat structure and landscape changes (Casatti et al., 2015a,b; Pease et al., 2012; Ribeiro et al., 2016). For example, structurally less complex and degraded streams are associated with the loss of species with particular requirements, such as species with benthic and rheophilic habits, 
Table 2

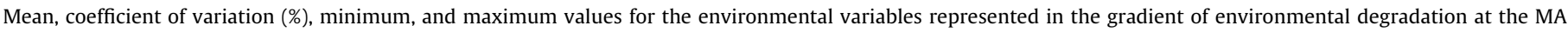
$(n=72)$, UPA $(n=91)$, and TA $(n=29)$ streams.

\begin{tabular}{|c|c|c|c|c|c|}
\hline Variables (\%) & Ecoregion & Mean & $\mathrm{CV}(\%)$ & Minimum & Maximum \\
\hline Native vegetation (catchment) & MA & 40.5 & 82.9 & 0.2 & 100.0 \\
\hline Trees and shrubs & MA & 65.2 & 58.8 & 0.0 & 100.0 \\
\hline Coarse litter & MA & 14.4 & 129.2 & 0.0 & 100.0 \\
\hline Native vegetation (catchment) & $\mathrm{TA}$ & 81.3 & 17.6 & 41.8 & 99.5 \\
\hline Native vegetation (500-m upstream) & TA & 71.6 & 31.3 & 10.5 & 100.0 \\
\hline Trees and shrubs & UPA & 24.4 & 134.9 & 0.0 & 100.0 \\
\hline Sand & UPA & 90.0 & 19.2 & 15.0 & 100.0 \\
\hline Macrophytes & UPA & 65.7 & 51.4 & 10.0 & 100.0 \\
\hline
\end{tabular}

with a good capacity for continuous swimming, and those which inhabit turbulent waters (e.g. low values of RCP, RAP, IVF, and FC and high values of CPC, RD, and EP) (Ribeiro et al., 2016).

We obtained average morphological values of 10 individuals for each species in each ecoregion (except for those with an abundance lower than 10 individuals, for which we measured all individuals). The area measures (RAP) were estimated using Zeiss ${ }^{\circledR}$ SteREO Discovery V12 stereomicroscope and AxioVision Zeiss ${ }^{\circledR}$ image software. Species that occurred in more than one ecoregion had their individuals analyzed separately in each ecoregion in order to take into account population differences in traits. These functional data are already partially available for species sampled in the UPA ecoregion (Casatti et al., 2015a).

\subsection{Taxonomic and functional indicators}

We described the assemblages in each ecoregion separately in relation to four groups of indicators (Table 1): indices of functional diversity based on presence/absence $\left(F D_{\mathrm{p} / \mathrm{a}}\right)$; indices of functional diversity weighted by abundance $\left(\mathrm{FD}_{\text {abund }}\right)$; indices of functional composition (mT); and indices based on taxonomic diversity (TDiv). $\mathrm{FD}_{\mathrm{p} / \mathrm{a}}$ was composed of five indices: Mean Pairwise Distance of Taxa (MPD), Mean of the Nearest Distance between Taxa (MNTD), Functional Diversity (FD), Functional Richness (FRic), and Functional Group Richness (FGR) (Table 1). FD abund was composed of five indices: MPD and MNTD, both weighted by species abundance, Functional Divergence (FDiv), Functional Dispersion (FDis), and the Rao's quadratic entropy. TDiv was composed of three indices: species richness, Shannon's diversity, and Simpson's diversity (Table 1).

Functional diversity indicators can be measured using different strategies (Petchey and Gaston, 2006). Some functional diversity indices (e.g., MPD, MNTD, and Rao) are computed directly based on the species pairwise functional distance (Ricotta and Szeidl, 2009). However, many others indices require more steps for their calculation, such as indices based on the distribution of species within multidimensional functional space (e.g., FRic, FDiv, and FDis), whose dimensions are the traits (Villéger et al., 2008), and indices based on dendrograms (e.g., FD and FGR), in which the species are the tips and their relative position on the tree reflect the hierarchy in the functional dissimilarities (Petchey and Gaston, 2002). Theses indices are the most widely used in the literature (Maire et al., 2015).

The multidimensional functional space used for the calculation of FRic, FDiv, and FDis was defined by vectors summarizing the trait dissimilarities between species obtained by a Principal Coordinates Analysis (PCoA) (Laliberté and Legendre, 2010). The dimensionality reduction was needed because some sites had less species than traits, which prevents the calculation of these indices (Villéger et al., 2008). Dendrogram-based indices (FD and FGR) were calculated using dendrograms created from the pairwise euclidean distance among species based on functional traits, using the Unweighted Pair Group Method with Arithmetic mean (UPGMA). We formed functional groups for FGR calculations considering the threshold of 0.7 in each functional dendrogram. Values for $\mathrm{mT}$ were calculated for each functional trait separately and they consisted of the community-weighted mean of each trait (Table 1). We logtransformed functional diversity indicators and species richness in order to reduce the influence of extreme values and to meet the requirements of normality in the subsequent statistical analyses. $R$ (version 3.2.2) was used to calculate all indices and to perform all statistical analyses (R Core Team, 2012).

\subsection{Data analysis}

Our analysis was carried out in three steps: 1) obtaining the gradient of environmental degradation based on environmental variables; 2) assessing the performance of indices by testing their response to the environmental gradient; 3 ) comparing the performance of indices among groups of indices and among ecoregions.

Step 1: we used a principal component analysis (PCA) from a correlation matrix that included non-collinear environmental variables (assessed by Pearson correlation) to emphasize the most important environmental gradients in each ecoregion. We used the broken-stick criterion for assessing the importance of the environmental variables to the principal components (Peres-Neto et al., 2003). Preliminary analysis of data indicated that the gradient of environmental degradation in the three ecoregions was not associated with the natural hydrological gradient. If they were, land use and habitat degradation variables and hydrological variables would be summarized by different axes, so that we could use the axis representing the formers as a composite predictor variable (i.e. gradient of environmental degradation).

Step 2: because stream fish assemblages are strongly influenced by the natural hydrological gradient (Ibañez et al., 2009), we used the residuals of the regressions between $\mathrm{FD}_{\mathrm{pa}}, \mathrm{FD}_{\mathrm{abund}}, \mathrm{mT}$, and TDiv with the three hydrological variables (width, depth, and water velocity; all standardized by the Z-score method) as potential indicators. Therefore, our taxonomic and functional indicators represent any variation that could not be explained by the natural hydrological gradient. We thus assessed all indices (the residuals) against the gradient of environmental degradation (site scores from the components extracted by PCA in step 1) by using linear regression. We used the resulting $\mathrm{R}$-squared values as performance indicators of the ability of each index to detect the gradient of environmental degradation.

Step 3: in order to evaluate the differential performance of indices to detect the environmental gradient we compared the mean performance of the indices (R-squared) among groups of indices $\left(\mathrm{FD}_{\mathrm{pa}}, \mathrm{FD}_{\mathrm{abund}}, \mathrm{mT}\right.$, and TDiv) and among ecoregions using two-way Analysis of Variance, followed by Fisher's Least Significant Difference (LSD) post hoc test. A significant main effect of group of indices would indicate differential performance among indices, while a significant main effect of region would indicate that the predictive power of indices varies across ecoregions. Finally, an interaction effect would indicate that the effect of indices is dif- 
ferent across ecoregions, which would mean that the performance of indices is not consistent across ecoregions. The latter result is expected, since according to our hypothesis, the performance of functional trait indicators is greater than taxonomic indicators and this varies among ecoregions, according to the length of the environmental gradient.

In order to evaluate the performance and consistency in the response of indices individually, we plotted indices in relation to their average performance across ecoregions and their interregion variation (measured by the coefficient of variation across ecoregions). The inter-region variation was used as an indicator of consistency for the capacity of indices to predict the environmental gradient.

\section{Results}

\subsection{Environmental gradient and biological data}

The first two axes of PCA explained 55.97\%, 53.87\%, and 50.3\% of the total variation in the environmental data of MA, TA, and UPA, respectively (see Supplementary material for detailed information). The first axis for MA and UPA and the second axis for TA summarized variables describing land use and habitat degradation and were retained for subsequent analysis. These axes accounted for $38.1 \%, 29.7 \%$, and $20.24 \%$ of the total variation in data, respectively. The variables significantly associated with the retained axes were: proportion of native vegetation cover in the catchment, proportion of trees and shrubs in the riparian zone and proportion of coarse litter in the stream bottom in MA; proportion of native vegetation cover in the catchment and proportion of native vegetation cover in a 500-m buffer around the site's catchment in TA; proportion of tree and shrubs in the riparian zone, proportion of macrophytes in the instream habitat, and the proportion of sand in the stream bottom (Table 2).

We recorded 131 species in MA, 59 in UPA, and 47 in TA (complete list in the Table $\mathrm{S} 1$ of the supplementary material). Richness varied from 7 to 36 (mean $=20.1)$ in MA, 7-28 (mean =17) in TA, and 3-21 (mean =10.21) in UPA. Non-native species occurred in UPA (three species) and MA (one species), but not in TA. Given that the data analysis with and without non-native species in the dataset showed similar results we decided not to include non-native species in our analysis in order to make the patterns comparable.

Communities from the three ecoregions were characterized in relation to the 20 indicators. For the calculation of indices based on the multidimensional functional space (FRic, FDis, and FDiv), there was the necessity for the reduction of the dimensionality of the functional trait matrices because the number of traits were higher than the number of species in some communities (see Material \& Methods). Six axes for MA and TA and two for UPA were retained, summarizing 95.2, 97.8, and $61.1 \%$ of the total interspecific trait variability, respectively. Furthermore, the cophenetic coefficient calculated with the functional dendrogram, used for FD and FGR calculations, was $0.87,0.83$, and 0.81 for MA, TA, and UPA, respectively; indicating a good representation of the original similarities among species.

\subsection{Performance of the group of indicators}

We found a significant interaction effect $\left(F_{(8,48)}=3.75, P=0.004\right)$ between groups of indices and ecoregions in the performance of indices in detecting the gradient of environmental degradation (Fig. 2). For MA, all groups of functional indicators performed better than the taxonomic diversity group (LSD post hoc test, $\mathrm{p}<0.01$, Fig. 2), and functional diversity indicators $\left(\mathrm{FD}_{\mathrm{pa}}\right.$ and $\left.\mathrm{FD}_{\mathrm{abund}}\right)$ per-

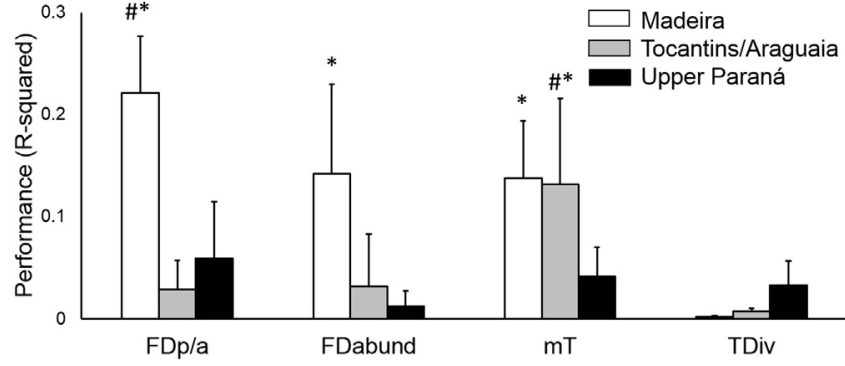

Fig. 2. Mean $\pm s d$ of the R-squared, indicating the performance of the functional diversity indices based on presence and absence $\left(\mathrm{FD}_{\mathrm{p} / \mathrm{a}}\right)$, functional diversity indices weighted by abundance (FD abund), indices based on the mean of traits ( $\mathrm{mT}$ ), and taxonomic diversity indices (TDiv) in the Madeira, Tocantins-Araguaia and Upper Paraná ecoregions. * indicate statistically higher performance than the other ecoregions without the asterisks for a given group of indicator at $\mathrm{p}<0.05$ (LSD post hoc test); \# indicate statistically higher performance of the group of indicator in relation to the all others groups for a given ecoregion at $\mathrm{p}<0.05$ (LSD post hoc test).

Table 3

Performance (R-squared) of functional and taxonomic indicators in the Madeira (MA), Tocantins-Araguaia (TA) and Upper Paraná (UPA) ecoregions. $\mathrm{FD}_{\mathrm{p} / \mathrm{a}}$ : functional diversity indices based on presence and absence; $\mathrm{FD}_{\text {abund }}$ : functional diversity indices weighted by abundance; mT: indices based on the mean of traits; TDiv: taxonomic diversity indices. For indices' codes see Table 1.

\begin{tabular}{lllll}
\hline Group of indicators & Indicators & MA & TA & UPA \\
\hline \multirow{3}{*}{ FD $_{\mathrm{p} / \mathrm{a}}$} & MPD & 0.22 & 0.01 & 0.00 \\
& MNTD & 0.40 & 0.08 & 0.00 \\
& FD & 0.10 & 0.01 & 0.07 \\
& FRic & 0.10 & 0.03 & 0.11 \\
& FGR & 0.29 & 0.01 & 0.11 \\
& MPD & 0.14 & 0.00 & 0.01 \\
FD $_{\text {abund }}$ & MNTD & 0.26 & 0.12 & 0.00 \\
& FDis & 0.15 & 0.01 & 0.01 \\
& FDiv & 0.01 & 0.02 & 0.04 \\
& Rao & 0.15 & 0.01 & 0.01 \\
& RD & 0.22 & 0.13 & 0.00 \\
RCP & 0.15 & 0.22 & 0.07 \\
mT & CPC & 0.12 & 0.23 & 0.05 \\
& IAV & 0.06 & 0.05 & 0.06 \\
& RAP & 0.19 & 0.19 & 0.02 \\
& PRO & 0.12 & 0.11 & 0.02 \\
& FC & 0.09 & 0.00 & 0.07 \\
TDiv & Richness & 0.00 & 0.00 & 0.06 \\
& Shannon & 0.00 & 0.01 & 0.02 \\
& Simpson & 0.00 & 0.01 & 0.01 \\
\hline
\end{tabular}

formed better than the corresponding indicators in TA and UPA (LSD post hoc test, $\mathrm{p}<0.01$, Fig. 2). In TA, functional composition indicators $(\mathrm{mT})$ were the highest performing indices (LSD post hoc test, $\mathrm{p}<0.01$, Fig. 2) and worked equally well as $\mathrm{mT}$ indices in MA. In UPA, functional and taxonomic indicators had low predictive power, with no variation among them (LSD post hoc test, $\mathrm{p}>0.49$, Fig. 2).

\subsection{Performance of the individual indicators}

The individual performance of indicators varied among indices and ecoregions (Table 3$)$. The indicators with better performance in MA were $\operatorname{MNTD}\left(R^{2}=0.40\right)$, FGR $\left(R^{2}=0.29\right)$, $\operatorname{MPD}\left(R^{2}=0.22\right)$, and $\mathrm{mT}(\mathrm{RD})\left(\mathrm{R}^{2}=0.22\right)$. In TA three $\mathrm{mT}(\mathrm{CPC}, \mathrm{RCP}$, and RAP) had the best performance $\left(R^{2}=0.23 ; 0.22 ; 0.19\right.$, respectively). In UPA the best performing indicators were of FRic and FGR $\left(R^{2}=0.11\right)$. Taxonomic diversity indicators had the worst performance in all three ecoregions $\left(\mathrm{R}^{2}<0.06\right)$ (Table 3$)$.

At least three of the seven functional traits $(\mathrm{mT})$ had the highest average performance and consistency (lower inter-region variation) (Fig. 3). Functional diversity indicators $\left(\mathrm{FD}_{\mathrm{p} / \mathrm{a}}\right.$ and $\left.\mathrm{FD}_{\mathrm{abund}}\right)$ had variable average performance and low consistency, while tax- 


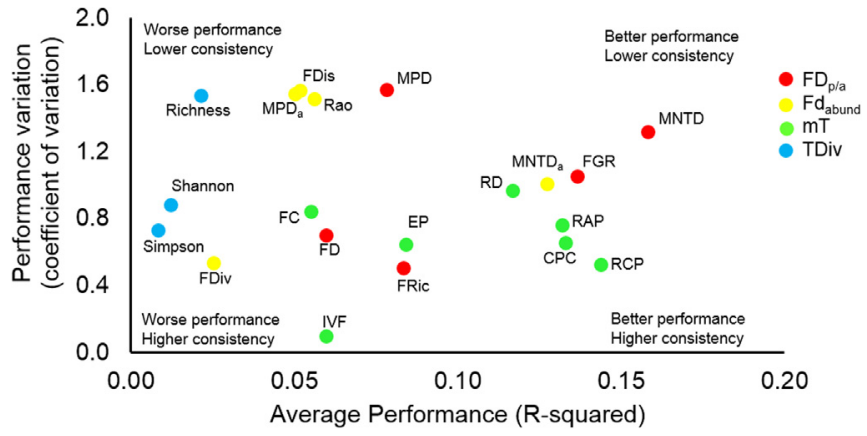

Fig. 3. Average performance of functional and taxonomic indicators across ecoregions and the inter-region variation in the performance. $\mathrm{FD}_{\mathrm{p} / \mathrm{a}}$ : functional diversity indices based on presence and absence; $\mathrm{FD}_{\text {abund }}$ : functional diversity indices weighted by abundance; $\mathrm{mT}$ : indices based on the mean of traits; TDiv: taxonomic diversity indices. For indices' codes see Table 1.

onomic diversity indicators, had the worst average performance (Fig. 3).

\section{Discussion}

We tested whether indicators of fish communities are associated with gradients of environmental degradation in streams. We expected that trait-based indicators (FD and $\mathrm{mT}$ ) would perform better because the spatial distribution of species along the gradients of human impacts is known to be associated with their traits (Flynn et al., 2009). Our results support the notion that the general condition of streams regarding their land use and habitat quality are captured by fish communities in streams from the three Neotropical ecoregions studied here, but not in the same way. While the functional structure of Amazonian communities (MA) exhibits a stronger environmental signature, communities from the most severely degraded ecoregion (UPA) showed a more unpredictable structure. Furthermore, the capacity of fish community indicators to predict the environmental gradient is variable withinand among-groups of indicators and among ecoregions, suggesting a context-dependent performance.

\subsection{Environmental gradient}

The gradient we studied encompasses heavily degraded streams, with large amounts of grass on stream banks and sandy stream bottoms, to better conserved streams, with higher amounts of coarse litter in stream channels, and native vegetation in the landscape (Bordignon et al., 2015; Casatti et al., 2015a; Leal et al., 2016). For two of the three ecoregions we studied (MA and UPA) variables associated with anthropogenic influences are the main source of environmental variability, as shown in the PCA results. In UPA, variables describing the instream habitat and the riparian ecotone were most important while in MA native vegetation in the catchment also contribute to environmental variability. In contrast, the natural hydrological gradient in TA is more evident, with the gradient of deforestation in the catchment acting as a secondary sources of variation among streams. These patterns reinforce the differences in the intensities and histories of land use and habitat degradation. In TA, the landscape is relatively well conserved, which makes the natural differences among streams more evident. Contrary, to UPA narrow riparian forest strips with variable width and conservation status are usually the only native remnants in the entire catchment, which explains the low variation in the catchment variables and higher importance of local variables for among-stream variability.

The proportion of sand in stream bottoms was associated with the anthropogenic gradient in UPA, while in MA the proportion of sand in stream bottoms was associated with the gradient of hydrological variation. In streams from UPA, the greater deposition of fine substrate (sand) when compared to the consolidated substrate (e.g., cobbles, boulders, rocks) is an indicator of siltation and has been associated with low habitat quality for fishes (Casatti et al., 2006). However, sand and fine sediments are naturally present in the streambed of Amazonian streams (Leal et al., 2016), offering a potential explanation for the mismatch between the variation in substrate composition and the variables associated with anthropogenic influences. Furthermore, previous studies have also showed that substrate composition influences the structure of fish communities in UPA more strongly (Casatti et al., 2006; Ribeiro et al., 2016) than in MA (Bordignon et al., 2015). Therefore, these results reinforce that the variables composing the environmental gradient in each ecoregion are reliable indicators of the loss of physical integrity of instream habitats and degradation of native vegetation in the ecotone, typical alterations in agroecosystems (Carvalho and Tejerina-Garro, 2015a; Casatti et al., 2006; Leal et al., 2016).

\subsection{Performance of the groups of indicators}

Our results show that taxonomic indicators are consistently less predictive of the environmental gradient than trait-based indicators, corroborating our hypothesis. These results reveal that the loss of gain of species and the changes in species abundance per se are not predictable along the environmental gradient. However, when these changes are evaluated in a trait-based perspective the predictive power of the indicators increases. This mismatch between taxonomic and functional diversity indicators is welldocumented in the literature (Carvalho and Tejerina-Garro, 2015b; Devictor et al., 2010; Gonçalves-Souza et al., 2015). Indeed, changes in species richness may not be directly related to changes in functional diversity, revealing different processes that structure assemblages, such as environmental filtering and niche complementarity (Mayfield et al., 2010).

The higher predictive power of functional trait indicators in MA is in accordance with our expectations. More specialized species and functionally overdispersed assemblages are found in near pristine streams from this ecoregion, in contrast to communities with a dominance of generalist and redundant species, a common scenario in deforested streams (Bordignon et al., 2015). Functional diversity (FD), as well as functional composition indicators ( $\mathrm{mT}$ ), successfully captured these changes. In TA, only $\mathrm{mT}$ indicators had higher performance, suggesting that the functional turnover (sensu Villéger et al., 2013) was the dominant process structuring stream fish assemblages. Perhaps, the narrower environmental gradient, in the absence of heavily degraded streams, prevented changes in functional diversity, while the changes in species abundance and the replacement of species with contrasting traits resulted in changes in functional composition.

In contrast to the MA and TA ecoregions discussed above, fish species from UPA were unpredictably distributed across the environmental gradient, as suggested by the lower performance of all groups of indicators. This region has a relatively older history of human influences, with the highest rates of deforestation, which started earlier than in the other two ecoregions. Native forest remnants comprise only $4 \%$ of the original vegetation coverage (Nalon et al., 2008) and the higher level of physical habitat degradation experienced by aquatic communities has previously been documented in this ecoregion (Casatti et al., 2009, 2015a). Considering that species tend to converge in terms of their traits in response to strong environmental constraints (Keddy, 1992), we would expect a high level of functional redundancy in the regional species pool. Functionally redundant communities (i.e., communities highly dominated by a few traits) present higher functional 
stability (Pillar et al., 2013), which means that the spatial variation in the species composition is not accompanied by changes in the functional structure in such communities, limiting our capacity to discriminate environmental gradients with these communities (low performance of indicators). Indeed, with the exception of a few streams located near some isolated forest fragments, fish assemblages from UPA show high redundancy, probably as a legacy of the historical filtering process (Casatti et al., 2015a).

We also hypothesized that narrower gradients would be predicted mainly by indices weighted by abundance. These expectations are based on the idea that such indices would be more sensitive to lower levels of perturbation, because changes in relative abundance are early signals of environmental change (Mouillot et al., 2013a). Thus, we would expect better performance from $\mathrm{FD}_{\text {abund }}$ in the UPA and TA ecoregions. Our data do not corroborate this hypothesis, as $\mathrm{FD}_{\mathrm{abund}}$ had similar, or worse performance, than $\mathrm{FD}_{\mathrm{p} / \mathrm{a}}$ indices. This is conceivably due to the fact that less abundant species are more important in determining the performance of the indices, which is the case whether rare species have a more predictable spatial distribution along the environmental gradient, or not (Petsch et al., 2015). When indices are weighted by abundance, these influences are overcome by dominant species. Furthermore, rare species tend to support unique combinations of traits, contributing disproportionally to the functional diversity of communities (Leitão et al., 2016; Mouillot et al., 2013b), making $\mathrm{FD}_{\mathrm{p} / \mathrm{a}}$ as, or even more, informative than abundance weighted indices.

\subsection{Performance of individual indicators}

Higher average performance and lower inter-region variation are good characteristics for reliable bioindicators across ecoregions. In our study, functional composition (mT) had such characteristics. The higher predictive power of $\mathrm{mT}$ is consistent with the findings from temperate streams and rivers (Carlisle and Hawkins, 2008; Statzner et al., 2005), and estuarine ecosystems (van der Linden et al., 2016). In our case, $\mathrm{mT}$ indices represent the relative importance of morphological traits related to habitat use and locomotion at the community level. Their higher predictive power indicates a spatial turnover of species with different niche requirements across the environmental gradient. For example, water column swimmers and limnophilic species tend to be replaced by benthic and rheophilic species in response to changes in instream conditions associated with the deforestation of areas surrounding streams (Casatti et al., 2012, 2015a). Additionally, mT indicators would have the additional advantage of being easier to estimate in comparison to FD indicators (Vandewalle et al., 2010). Thus, in regions where autoecological knowledge is lacking for the majority of species, as is the case in the tropics, the use of functional composition indicators based on habitat use and locomotion seem to be a good choice for assessing the environmental quality in running waters.

The best performing functional diversity indices are MNTD and FGR. However, they are less consistent, having the best performance in MA but not in the other two ecoregions. MNTD is an index sensitive to changes in the terminal branches of a functional dendrogram (Webb, 2000), while FGR is sensitive to the addition or loss of groups of species that share traits (i.e. functional groups). Thus, these indices should capture different processes in the response of stream assemblages across the environmental gradient. While MNTD should capture small changes in the functional space occupied by species, i.e., the loss of redundant species, FGR responds to major drift in the functional structure of communities. In fact, these are complementary responses that could occur in communities along a large breadth of environmental conditions, as found in MA.

\subsection{Implications for environmental monitoring}

The main implication of our study for applied ecology is recognizing that functional indicators outperform taxonomic indicators at detecting gradients of environmental degradation. The former have the additional advantage of greater potential for transferability across regions (Vandewalle et al., 2010). The traits we used provide ecologically meaningful information regarding locomotion and habitat use of species (Oliveira et al., 2010), and could be easily measured by trained technicians. However, our results do not support the existence of a universal indicator (Hevia et al., 2016), as the performance of indicators depends on the ecoregion and probably the breadth of the environmental gradient.

Our results of the average of the individual performance of the indices show that the better indicators (higher performance and consistency) had only approximately $15 \%$ of their variation explained by the environmental gradient on average (see Fig. 3). However, the average values are influenced by the variability in the response of indicators, especially the low diversity-environment relationship in UPA. Considering the other two ecoregions, a higher variation in the functional indicators are explained by the environmental gradient ( $\sim 20$ to $40 \%$ ), which is relatively high when compared with other studies (Casatti et al., 2015a; Moretti et al., 2009; Vandewalle et al., 2010), reinforcing the predictive power of the functional indicators.

\subsection{Concluding remarks}

The Neotropical region has one of the richest biotas in the world, supporting high functional diversity (Toussaint et al., 2016) and essential ecosystem services (Tundisi and Matsumura-Tundisi, 2008), but the development of management and conservation tools for protect this diversity have been incipient (Ruaro and Gubiani, 2013). In this context, our study provides one the first attempts to comparatively evaluate the performance of different functional trait indicators in detecting environmental degradation in different ecoregions. This approach can be insightful to the understanding of the consistency in the performance of ecological indicators, which is especially relevant in the Neotropical region, where comparative studies on stream fish on broader spatial scale are scarce (Dias et al., 2016).

In summary, our results indicate that functional trait indicators are better than traditional descriptors of communities at predicting fish responses to a gradient of environmental degradation. We also highlight the need for caution when generalizing functional diversity indicators across ecoregions, as the performance of the majority are context-dependent, although functional composition indicators are promising transferable indicators of environmental quality.

\section{Acknowledgements}

We are grateful to two anonymous reviewers that provided constructive criticisms that improved the manuscript; to the Laboratory of Ichthyology (UNESP) and the Laboratory of Biogeography and Aquatic Ecology (UEG) for data collection; to Patrick T.A. Martins, Pedro P. Borges, Hugo O. Barbosa, and Gabriel L. Brejão for land cover analysis; to Mariela M. Ribeiro, Dianne M. A. Silva, María Angélica P. Mayorga for ecomorphological measurements; to CNPq (482185/2012-0), FAPEG (201210267000703 and AUXPE2036/2013), and FAPESP (2001/13340-7 and 2010/174948 ) for research funding. FBT and LC receive research grants from CNPq (302158/2015 and 4301755/2013-2, respectively). This study is part of a post-doc project developed by FBT at the São Paulo State University (PROPE/UNESP 925). 


\section{Appendix A. Supplementary data}

Supplementary data associated with this article can be found, in the online version, at http://dx.doi.org/10.1016/j.ecolind.2016. 12.041 .

\section{References}

Abell, R., Thieme, M.L., Revenga, C., Bryer, M., Kottelat, M., Bogutskaya, N., Coad, B., Mandrak, N., Balderas, S.C., Bussing, W., Stiassny, M.L.J., Skelton, P., Allen, G.R., Unmack, P., Naseka, A., Ng, R., Sindorf, N., Robertson, J., Armijo, E., Higgins, J.V. Heibel, T.J., Wikramanayake, E., 2008. Freshwater ecoregions of the world: a new map of biogeographic units for freshwater biodiversity conservation. Bioscience 58, 403-414.

Allan, J.D., 2004. Landscapes and riverscapes: the influence of land use on stream ecosystems. Annu. Rev. Ecol. Syst. 35, 257-284.

Alves, D.S., Pereira, J.L.G., Sousa, C.L., Soares, J.V., Yamaguchi, F., 1998. Classification of the deforested area in central Rondônia using TM imagery. In: Anais IX Simpósio Brasileiro de Sensoriamento Remoto. INPE, Santos, Brasil, pp. 1421-1432.

Bonada, N., Prat, N., Resh, V.H., Statzner, B., 2006. Developments in aquatic insect biomonitoring: a comparative analysis of recent approaches. Annu. Rev. Entomol. 51, 495-523.

Bordignon, C.R., Casatti, L., Pérez-Mayorga, M.A., Teresa, F.B., Brejão, G.L., 2015. Fish complementarity is associated to forests in Amazonian streams. Neotrop. Ichthyol. 13, 579-590.

Borges, P.P., Teresa, F.B., Martins, P.T.A., Nabout, J.C., 2015. Relative influence of direct and indirect environmental effects on sestonic chlorophyll- $a$ concentration in Cerrado streams. Acta Limnol. Bras. 27, 301-310.

Carlisle, D.M., Hawkins, C.P., 2008. Land use and the structure of western US stream invertebrate assemblages: predictive models and ecological traits. J. North Am. Benthol. Soc. 27, 986-999.

Carvalho, R.A., Tejerina-Garro, F.L., 2015a. Environmental and spatial processes: what controls the functional structure of fish assemblages in tropical rivers and headwater streams? Ecol. Freshw. Fish 24, 317-328.

Carvalho, R.A., Tejerina-Garro, F.L., 2015b. Relationships between taxonomic and functional components of diversity: implications for conservation of tropical freshwater fishes. Freshw. Biol. 60, 1854-1862.

Casatti, L., Langeani, F., Ferreira, C.P., 2006. Effects of physical habitat degradation on the stream fish assemblage structure in a pasture region. Environ. Manage. 38, 974-982

Casatti, L., Ferreira, C.P., Carvalho, F.R., 2009. Grass-dominated stream sites exhibi low fish species diversity and dominance by guppies: an assessment of two tropical pasture river basins. Hydrobiologia 632, 273-283.

Casatti, L., Teresa, F.B., Gonçalves-Souza, T., Bessa, E., Manzotti, A.R., Gonçalves, C.S., Zeni, J.O., 2012. From forests to cattail: how does the riparian zone influence stream fish? Neotrop. Ichthyol. 10, 205-214.

Casatti, L., Teresa, F.B., Zeni, J.O., Ribeiro, M.D., Brejão, G.L., Ceneviva-Bastos, M., 2015a. More of the same: high functional redundancy in stream fish assemblages from tropical agroecosystems. Environ. Manage. 55, 1300-1314.

Casatti, L., Pérez-Mayorga, M.A., Carvalho, F.R., Brejão, G.L., Costa, I.D., 2015b. The stream fish fauna from the rio Machado basin, Rondônia State, Brazil. Check List 9, 1496-1504.

de Bello, F., Lepš, J., Lavorel, S., Moretti, M., 2007. Importance of species abundance for assessment of trait composition: an example based on pollinator communities. Community Ecol. 8, 163-170.

Devictor, V., Mouillot, D., Meynard, C., Jiguet, F., Thuiller, W., Mouquet, N., 2010. Spatial mismatch and congruence between taxonomic: phylogenetic and functional diversity: the need for integrative conservation strategies in a changing world. Ecol. Lett. 13, 1030-1040.

Dias, M.S., Zuanon, J., Couto, T.B.A., Carvalho, M., Carvalho, L.N., Espírito-Santo, H.M.V., Frederico, R., Leitão, R.P., Mortati, A.F., Pires, T.H.S., Torrente-Vilara, G., Vale, J., dos Anjos, M.B., Mendonça, F.P., Tedesco, P.A., 2016. Trends in studies of Brazilian stream fish assemblages. Nat. Cons. 24, 106-111.

Dolédec, S., Statzner, B., Bournard, M., 1999. Species traits for future biomonitoring across ecoregions: patterns along a human-impacted river. Freshw. Biol. 42, 737-758.

Esselman, P.C., Allan, J.D., 2010. Relative influences of catchment- and reach-scale abiotic factors on freshwater fish communities in rivers of northeastern Mesoamerica. Ecol. Freshw. Fish 19, 439-454

Fernandes, L.C., Guimarães, S.C.P., 2002. Atlas Geoambiental de Rondônia. SEDAM, Porto Velho.

Flynn, D.F.B., Gogol-Prokurat, M., Nogeire, T., Molinari, N., Richers, B.T., Lin, B.B., Simpson, N., Mayfield, M.M., DeClerck, F., 2009. Loss of functional diversity under land use intensification across multiple taxa. Ecol. Lett. 12, 22-33.

Garnier, E., Cortez, J., Billes, G., Navas, M.L., Roumet, C., Debussche, M., Laurent, G., Blanchard, A., Aubry, D., Bellmann, A., Neill, C., Toussaint, J.P., 2004. Plant functional markers capture ecosystem properties during secondary succession. Ecology 85, 2630-2637

Gonçalves-Souza, T., Santos, A.J., Romero, G.Q., Lewinsohn, T.M., 2015. Conservation along a hotspot rim: spiders in Brazilian coastal restingas. Biodivers. Conserv. 24, 1131-1146.

Hevia, V., Carmona, C.P., Azcárate, F.M., Torralba, M., Alcorlo, P., Ariño, R., Lozano, J., Castro-Cobo, S., González, J.A., 2016. Effects of land use on taxonomic and functional diversity: a cross-taxon analysis in a Mediterranean landscape. Oecologia 181, 959-970.

Ibañez, C., Belliard, J., Hughes, R.M., Irz, P., Kamdem-Toham, A., Lamouroux, N., Tedesco, P.A., Oberdorff, T., 2009. Convergence of temperate and tropical stream fish assemblages. Ecography 32, 658-670.

Keck, B.P., Marion, Z.H., Martin, D.J., Kaufman, J.C., Harden, C.P., Schwartz, J.S. Strange, R.J., 2014. Fish functional traits correlated with environmental variables in a temperate biodiversity hotspot. PLoS One 9, e93237, http://dx. doi.org/10.1371/journal.pone.0093237.

Keddy, P.A., 1992. Assembly and response rules: two goals for predictive community ecology. J. Veg. Sci. 3, 157-164

Kemenes, A., Forsbergb, B.R., 2014. Factors influencing the structure and spatial distribution of fishes in the headwater streams of the Jaú River in the Brazilian Amazon. Braz. J. Biol. 74, S23-S32.

Laliberté, E., Legendre, P., 2010. A distance-based framework for measuring functional diversity from multiple traits. Ecology 91, 299-305.

Lavorel, S., Grigulis, K., McIntyre, S., Garden, D., Williams, N., Dorrough, J., Berman, S., Quétier, F., Thébault, A., Bonis, A., 2008. Assessing functional diversity in the field-methodology matters! Funct. Ecol. 22, 134-147.

Leal, C.G., Pompeu, P.S., Gardner, T.A., Leitão, R.P., Hughes, R.M., Kaufmann, P.R. Zuanon, J., Paula, F.R., Ferraz, S.F.B., Thomson, J.R., Nally, R.M., Ferreira, J., Barlow, J., 2016. Multi-scale assessment of human-induced changes to Amazonian instream habitats. Landsc. Ecol. 31, 1725-1745.

Leitão, R.P., Zuanon, J., Villéger, S., Williams, S.E., Baraloto, C., Fortune, C.F., Mendonça, F.P., Mouillot, D., 2016. Rare species contribute disproportionately to the functional structure of species assemblages. Proc. R. Soc. Biol. Sci. Ser. B 283, 1-9.

Maire, E., Grenouillet, G., Brosse, S., Villéger, S., 2015. How many dimensions are needed to accurately assess functional diversity? A pragmatic approach for assessing the quality of functional spaces. Global Ecol. Biogeogr. 24, 728-740.

Mayfield, M.M., Bonser, S.P., Morgan, J.W., Aubin, I., McNamara, S., Ves, P.A., 2010. What does species richness tell us about functional trait diversity? Predictions and evidence for responses of species and functional trait diversity to land-use change. Global Ecol. Biogeogr. 19, 423-431.

Ministério do Meio Ambiente, 2006. Secretaria de recursos Hídricos. In: Caderno Da Região Hidrográfica Do Tocantins-Araguaia. MMA, Brasília.

Monbeig, P., 1998. Pioneiros e Fazendeiros de São Paulo. Hucitec, São Paulo.

Moretti, M., de Bello, F., Roberts, S.P.M., Potts, S.G., 2009. Taxonomical vs functional responses of bee communities to fire in two contrasting climatic regions. J. Anim. Ecol. 78, 98-108.

Mouillot, D., Graham, N.A.J., Villéger, S., Mason, N.W.H., Bellwood, D.R., 2013a. A functional approach reveals community responses to disturbances. Trends Ecol. Evol. 28, 167-177.

Mouillot, D., Bellwood, D.R., Baraloto, C., Chave, J., Galzin, R., Harmelin-Vivien, M., Kulbicki, M., Lavergne, S., Lavorel, S., Mouquet, N., Paine, C.E.T., Renaud, J., Thuiller, W., 2013b. Rare species support vulnerable functions in high-diversity ecosystems. PLoS Biol. 11, 1-11.

Nalon, M.A., Matto, I.S.A., Franco, G.A.D.C., 2008. Meio físico e aspectos da vegetação. In: Rodrigues, R.R., Bononi, V.L.R. (Eds.), Diretrizes para Conservação e Restauração da Biodiversidade no Estado de São Paulo. Instituto de Botânica, São Paulo, pp. 12-21.

Oliveira, E.F., Goulart, E., Breda, L., Minte-Vera, C.V., Paiva, L.R.S., Vismara, M.R., 2010. Ecomorphological patterns of the fish assemblage in a tropical floodplain: effects of trophic, spatial and phylogenetic structures. Neotrop. Ichthyol. 8, 569-586.

Pavoine, S., Dolédec, S., 2005. The apportionment of quadratic entropy: a useful alternative for partitioning diversity in ecological data. Environ. Ecol. Stat. 12 $125-138$.

Pease, A.A., Gonzalez-Días, A.A., Rodiles-Hernández, R., Winemiller, K.O., 2012. Functional diversity and trait-environment relationships of stream fish assemblages in a large tropical catchment. Freshw. Biol. 57, 1060-1075

Peres-Neto, P.R., Jackson, D.A., Somers, K.M., 2003. Giving meaningful interpretation to ordination axes: assessing loading significance in principal component analysis. Ecology 84, 2347-2363.

Petchey, O.L., Gaston, K.J., 2002. Functional diversity (FD), species richness and community composition. Ecol. Lett. 5, 402-411.

Petchey, O.L., Gaston, K.J., 2006. Functional diversity: back to basics and looking forward. Ecol. Lett. 9, 741-758

Petsch, D.K., Pinha, G.D., Dias, J.D., Takeda, A.M., 2015. Temporal nestedness in Chironomidae and the importance of environmental and spatial factors in species rarity. Hydrobiologia 745, 181-193.

Pillar, V.D., Blanco, C.C., Müller, S.C., Sosinski, E.E., Joner, F., Duarte, L.D.S., 2013. Functional redundancy and stability in plant communities. J. Veg. Sci. 24, 963-974.

Poff, N.L.R., 1997. Landscape filters and species trait: towards mechanistic understanding and prediction in stream ecology. J. North Am. Benthol. Soc. 16, 391-409.

Pont, D., Hugueny, B., Beier, U., Goffaux, D., Melcher, A., Noble, R., Rogers, C., Roset, N., Schmutz, S., 2006. Assessing river biotic condition at a continental scale: a European approach using functional metrics and fish assemblages. J. Appl. Ecol. $43,70-80$.

Pool, T.K., Olden, J.D., Whittier, J.B., Paukert, C.P., 2010. Environmental drivers of fish functional diversity and composition in the Lower Colorado River Basin. Can. J. Fish. Aquat. Sci. 67, 1791-1807. 
Poole, K.E., Downing, J.A., 2004. Relationships of declining mussel biodiversity to stream-reach and watershed characteristics in an agricultural landscape. J. North Am. Benthol. Soc. 23, 114-125.

R Core Team, 2012. R: a Language and Environment for Statistical Computing. R Foundation for Statistical Computing, Vienna, Austria http://www.R-project. org/.2012.

Ribeiro, M.D., Teresa, F.B., Casatti, L., 2016. Use of functional traits to assess changes in stream fish assemblages across a habitat gradient. Neotrop. Ichthyol. 14, e140185.

Ricotta, C., Szeidl, L., 2009. Diversity partitioning of Rao's quadratic entropy. Theor. Popul. Biol. 76, 299-302.

Ruaro, R., Gubiani, E.A., 2013. A scientometric assessment of 30 years of the Index of Biotic Integrity in aquatic ecosystems: applications and main flaws. Ecol. Indic. 29, 105-110.

Shannon, C.E., 1948. A mathematical theory of communication. Bell Syst. Technol. J. $27,379-423$

Silva, A.M., Nalon, M.A., Kronka, F.J.N., Álvares, C.A., Camargo, P.B., Martinelli, L.A., 2007. Historical land-cover/use in different slope and riparian buffer zones in watersheds of the State of São Paulo. Brazil Sci. Agric. 64, 325-335.

Simpson, E.H., 1949. Measurement of diversity. Nature 163 (4148), 688

Southwood, T.R.E., 1977. Habitat, the templet for ecological strategies? J. Anim. Ecol. 46, 337-365.

Statzner, B., Bis, B., Dolédec, S., Usseglio-Polatera, P., 2001. Perspectives for biomonitoring at large spatial scales: a unified measure for the functional composition of invertebrate communities in European running waters. Basic Appl. Ecol. 2, 73-85.

Statzner, B., Bady, P., Dolédec, S., Scholl, F., 2005. Invertebrate traits for the biomonitoring of large European rivers: an initial assessment of trait patterns in least impacted river reaches. Freshw. Biol. 50, 2136-2161.

Sthraler, A.N., 1957. Quantitative analysis of watershed geomorphology. Trans. Am. Geophys. Union 38, 913-920.

Teresa, F.B., Casatti, L., 2012. Influence of forest cover and mesohabitat types on functional and taxonomic diversity of fish communities in Neotropical lowland streams. Ecol. Freshw. Fish 21, 433-442.
Tolkamp, H.H., 1985. Using several indices for biological assessment of water quality in running water. Verh. Internat. Verein Limnol. 22, 2281-2286.

Tonn, W.M., Magnuson, J.J., Rask, M., Toivonen, J., 1990. Intercontinental comparison of small-lake fish assemblages: the balance between local and regional processes. Am. Nat. 136, 345-375.

Toussaint, A., Charpin, N., Brosse, S., Villéger, S., 2016. Global functional diversity of freshwater fish is concentrated in the Neotropics while functional vulnerability is widespread. Sci. Rep. 6, 1-9.

Townsend, C.R., Hildrew, A.G., 1994. Species traits in relation to a habitat template for river systems. Freshw. Biol. 31, 265-275.

Tundisi, J.G., Matsumura-Tundisi, T., 2008. Biodiversity in the Neotropics: ecological, economic and social values. Braz. J. Biol. 68 (Suppl. 4), 913-915.

Vandewalle, M., de Bello, F., Bolger, M.P.B.T., Dolédec, S., Dubs, F., Feld, C.K., Harrington, R., Harrison, P.A., Lavorel, S., Silva, P.M., Moretti, M., Niemelä, J., Santos, P., Sattler, T., Sousa, J.P., Sykes, M.T., Vanbergen, A.J., Woodcock, B.A., 2010. Functional traits as indicators of biodiversity response to land use changes across ecosystems and organisms. Biodivers. Conserv. 19, 2921-2947.

Villéger, S., Mason, N.W.H., Mouillot, D., 2008. New multidimensional functional diversity indices for a multifaceted framework in functional ecology. Ecology 89, 2290-2301.

Villéger, S., Grenouillet, G., Brosse, S., 2013. Decomposing functional $\beta$-diversity reveals that low functional $\beta$-diversity is driven by low functional turnover in European fish assemblages. Global Ecol. Biogeogr. 22, 671-681.

Violle, C., Navas, M.L., Vile, D., Kazakou, E., Fortunel, C., Hummel, I., Garnier, E., 2007. Let the concept of trait be functional! Oikos 116, 882-892.

Walker, B.H., 1992. Biodiversity and ecological redundancy. Conserv. Biol. 6, 18-23.

Watson, D.J., Balon, E.K., 1984. Ecomorphological analysis of fish taxocenes in rainforest streams on northern Borneo. J. Fish Biol. 25, 371-384.

van der Linden, P., Marchini, A., Dolbeth, M., Patrício, J., Veríssimo, H., Marques, J.C. 2016. The performance of trait-based indices in an estuarine environment. Ecol. Indic. 61, 378-389.

Webb, C.O., 2000. Exploring the phylogenetic structure of ecological communities: an example for rains forest trees. Am. Nat. 156, 145-155. 